\title{
W Wessels
}

\section{PROPHETS AT LOGGERHEADS. ACCUSATIONS OF ADULTERY IN JEREMIAH 23:9-15}

\begin{abstract}
The focus of this article is on one aspect of the raging conflict between the prophetic parties addressed in Jeremiah 23:9-15. In this section the aspect of disloyalty to Yahweh is raised as hampering factor for being a true prophet. The research investigates the relationship between doing evil (cf. words such as adultery and ungodly/profane conduct) and the effect on the land (cf curse on the land, the land mourns, pastures drying up - 23:10-11). The research also entertains the relation with the next set of verses (23:13-15) which explicitly mentions the worship of Baal, the vegetation god, as reason for the disloyalty. The false prophets, with their adulterous way of living, are part of a leadership that failed the people of Judah and Yahweh.
\end{abstract}

\section{INTRODUCTION}

The composition and redaction history of the Book of Jeremiah is, as every theologian knows, a complicated matter. The book consists of many blocks of material, of which Jeremiah 21:1-24:10 is one. A suitable heading for this block of material would be: failed leadership. The concern of this paper is with this block of prophetic oracles, in particular the section in 23:9-40 concerning the false prophets. The key figure here is the prophet Jeremiah, a man who was in conflict with both the kings and the prophets in the last years before the Babylonian exile.

Prof W J Wessels, Departement of Old Testament and Ancient Near Eastern Studies, University of South Africa, Pretoria.E-mail: wessewj@unisa.ac.za

Acta Theologica

2011 31(2): 346-362

doi: http://dx.doi.org/10.4314/actat.v31i2.18

ISSN 1015-8758

C UVIUFS

<http://www.uovs.ac.za/ActaTheologica> 
Jeremiah 23:9-40 consists of a "block" of oracles that address the topic of true and false prophets. A recurring theme in this section is the idea of the "word/s of Yahweh". Some of the issues raised regarding "the word of Yahweh" are: who receives it, where and how it is received, what are true words, what hampers the "truth" of the word and what are the consequences of false words. Another theme that runs almost as a counterpart to the concept of "word" is the theme of visions or dreams.

The focus of this paper will be on one aspect of the raging conflict between the prophetic parties addressed in Jeremiah 23:9-15. In this section the issue of disloyalty to Yahweh is raised as a hampering factor in being a true prophet. In this paper, I will investigate the relationship between doing evil (cf. words such as adultery and ungodly/profane conduct) and the effect on the land (cf. curse on the land, the land mourns, pastures drying up -23:10-11). I will also examine the relationship, if any, between Jeremiah 23:9-12 and the next set of verses (23:13-15), which explicitly mentions the worship of Baal, the fertility god, as the reason for this disloyalty.

The section on the prophets in 23:9-40 consists of six poetic and prose sections, namely 23:9b-12; 13-15; 16-17; 18-22; 23-32 and 33-40 (Stulman 2005:215; Rudolph 1968:150-155).

The first passage commences in verse 9 with an emotional statement by Jeremiah on how Yahweh's holy words affect him in person. His body reacts like that of a person who is jittery because he has drunk too much alcohol. $\mathrm{He}$ is overwhelmed by Yahweh's word. In the next verses he describes the ethical demise in the land of Judah and the resulting disastrous consequences for the land and nature itself. The key to this disaster, Jeremiah says, is the prophets who are seriously "off track": they abuse their power and they are morally depraved. For this Yahweh will bring calamity on them.

The second pericope, consisting of 23:13-15, is another indictment (cf. Fretheim 2002:331). It explicitly states the transgressions of the prophets in Jerusalem. They are adulterers who lie and cheat; they help people to do wrong, which results in their drifting away from Yahweh. A comparison is drawn between the prophets in Jerusalem and the adulterous inhabitants of Sodom and Gomorrah (Gen 19). This terrible state of affairs will lead to the prophets eating bitter food and drinking poisoned water. The prophets of Jerusalem are blamed for the fact that their ungodliness has contaminated the whole land of Judah.

\section{EXPOSITION OF JEREMIAH 23:9-15}

The section Jeremiah 23:9-15 consists of two units: 9-12 and 13-15. Verse 9a commences with a heading indicating that this particular collection of oracles 
is about the prophets (cf. Werner 1997:201). In fact, it is a collection of oracles aimed as a polemic against so-called false prophets. This theme occurs in several places in the book of Jeremiah, such as 14:14-16 and chapters 27-29.

In the second part of verse 9, the author of the oracle, presumably the prophet Jeremiah, describes the bodily effect that Yahweh and his words had on him. Of significance here is the reference to Yahweh's word as holy or sacred words. This reference in particular sets the tone for the contrasting description of ungodliness that follows in verses 10-12 and 13-15. Verses 23:9-12 is a short poem (Carroll 1986:452), reflecting the reaction of a speaker on the bad condition of the land. Verses 10 and 11 are linked together by three occurrences of the particle ki. Verse 12 is introduced by laken (particle preposition I + particle adverb ken), which describes the outcome of the transgression mentioned.

The following three verses (13-15) are also regarded as poetry (Carroll 1986:455; Lundbom 2004:185). Of these three verses, 13 and 14 belong together and display the contrast created between the prophets of Samaria and those of Jerusalem. Verse 15 links backwards to 13-14, expressing the consequences (laken) of the ill-doings of the prophets of Jerusalem. Carroll makes a very important observation about the divisions of these oracles and says:

So in following the exegesis of each section of the cycle allowance must be made for alternative interpretations which a different division would permit (Carroll 1986:455).

\subsection{Jeremiah 23:9-12}

As I said earlier on, Jeremiah 23:9 sets the tone of holiness with reference to Yahweh and his words. In contrast to this, verse 10 describes the people who act disgracefully and the destruction this has wrought on the land.

Jeremiah 23:10 is introduced by ki, a particle conjunction homonym. There are three instances of $k i$ to follow (vss 10, 11), and as McKane (1986:570) has argued, they should be taken as asseveratives. The words of Yahweh therefore follow from verse 10 to verse 12 .

The matter of $k i$ repeated three times is not the only problem; verse 10 has many more issues that exegetes have to deal with. McKane (1986: 569$570)$ provides a detailed discussion of how scholars such as Duhm (1901), Rudolph (1968) Giesebrecht and Janzen suggest the changes that should be made to the text. These scholars regard $10 \mathrm{~b}$ as secondary and suggest that it should be scrapped (the reference to "oath" or "curse"). However, as McKane indicates, not much is gained by following their suggestions. It seems 
better to accept the Masoretic text (MT) as it is and attempt to understand it in its current form. McKane suggests that the MT should be followed, but with one exception, that is, to read miphne elê (the Septuagint and the Peshitta) rather than miphne 'alla. If this suggestion is accepted, then the reference is to Yahweh and his holy words ${ }^{1}$ at the end of verse 9 and not to the adulterers, because 10a is omitted in the Septuagint. These problems in the MT were discussed by a panel of academics responsible for a Dutch Bible translation project (cf. De Waard 2003:100-101); the panel concluded that both the MT version (because of a curse) and the LXX suggestion of a demonstrative pronoun plural (because of these [things]) are text possibilities. However, it seems better to keep to the MT, because the changes are not essential for making sense of the verse as it currently stands. I will also argue, at a later stage, that the terminology used in the section under discussion alludes to the covenant and that the reference to the oath supports this idea. As Lundbom (2004:183) also indicates, 'alla should be retained, because there is assonance with the verb 'abelah.

Verses 10-12 tell us why the speaker (the prophet) is so upset. Verse 9 has indicated that, because of Yahweh and his holy words, what is happening in Judean society is not acceptable. In contrast to Yahweh, who is holy and whose words are holy, the land of Judah is full of adulterers. This term, according to Lundbom (2004:182), is "a general term for an apostate people". In 9:1 (Eng vs 2) the same term is used: the people of Judah are called "adulterers", and is qualified in the same sentence by the reference to them as "a crowd of unfaithful people" (NIB), or as "a band of traitors" (NRS). The context of 8:18-9:3 makes it clear that the people are regarded as unfaithful because they worship useless idols. What is interesting here is that, similar to $23: 9$, the speaker (the prophet) in this context is also experiencing strong emotions and has bodily reactions because of these strong emotions. In both instances the prophets (the speakers) label the people "adulterers" for what they have been doing. The qal form of the verb "to commit adultery" is used in Jeremiah 5:7 as a reference to worship of false gods and in 7:9 to the worship of Baal and other gods. This also applies to Jeremiah 3:8 (Piel form of the verb as in 23:10), where the unfaithfulness of Israel and Judah refers to the worship of idols made of stone and wood. However, other exegetes, such as Lundbom (2004:187) and McKane (1986:569)2, take adultery as literally

1 The Septuagint reads instead of "the words of his holiness" the phrase "the excellence of his glory".

2 McKane (1986:569) refers to Bright, Holladay and Rudolph, who also regard adultery in this instance literally. 
meaning "sexual immorality" and do not regard it as a metaphor for religious apostasy. ${ }^{3}$

It seems safe to say that, in most cases in Jeremiah, the term "adulterers" refers to Judah's unfaithfulness in terms of the worship of false gods and idols (cf. Craigie, Kelly \& Drinkard 1991:337; Weiser 1969:202). Overholt (1970:50) argues that the term "adulterers" indicates social and moral offence (cf Duhm 1901:183), but also points to Baal worship (cf. Thompson 1980:493-494), a view which is important for the argument put forward in this paper. Both Hosea and Jeremiah use the term "adulterers" when referring to the worship and cultic practices of Baal religion. Instead of worshiping the true and holy God, the people addressed in verse 10 are labelled adulterers for worshipping false gods. Sharp (2003:116-118) ${ }^{4}$ has shown that, in Jeremiah 3:3-8; 5:7 and $23: 10-14$, the term "adultery" has a metaphorical meaning of disloyalty to Yahweh, whereas in 7:9 and 29:23 it refers to sexual infidelity. In terms of the covenant, which is strongly promoted in the book of Jeremiah, such forms of adultery would be regarded as disloyalty to Yahweh and as breaking the covenant (cf. Overholt 1970:50-51). If it is fitting to regard the adultery as a breaking of the covenant between Yahweh and his elected people, then the reference to the "curse" ('alla) would imply an oath or curse relating to the covenant. In Ezekiel 16:59, the term 'alla is used in terms of the breaking of the covenant oath. The same applies to Ezekiel 17:18:

Because he despised the oath and broke the covenant, because he gave his hand and yet did all these things, he shall not escape (NRS).

In Isaiah 24:4-6 the breaking of the covenant is mentioned, as is the curse on the earth and the resulting drought.

3 Jones (1992:305) refers to instances where adultery is understood as immoral behavior, but also to instances where apostasy is implied. In his view, Jeremiah probably intended the application to be open both ways (cf. also Huey 1993:214).

4 The view presented by Sharp (2003:118) that adultery can also refer to foreign political alliances has merit, but it seems unlikely in the context of Jeremiah 23:9-15. In this context the violation of the covenant and its obligations seem to demonstrate disloyalty to Yahweh. The prophets are the leading functionaries who have transgressed and will pay the consequences. They have spread the ungodliness (pollution/ profaneness) throughout the land and the consequence is drought and calamity. 
24:4 The earth dries up and withers, the world languishes and withers; the heavens languish together with the earth.

24:5 The earth lies polluted under its inhabitants; for they have transgressed laws, violated the statutes, broken the everlasting covenant.

24:6 Therefore a curse devours the earth, and its inhabitants suffer for their guilt; therefore the inhabitants of the earth dwindled, and few people are left (NRS).

Lundbom (2004:183) has indicated that drought is part of the curses mentioned in Deuteronomy 28:23-24 (when people break the covenant by disobeying Yahweh's commands).

According to the speaker in verse 10 , the land mourns because ${ }^{5}$ of the curse. The result of the curse is that the pastures of the wilderness ${ }^{6}$ have dried up. The KJV translates the verse: "the pleasant places of the wildness are dried up". The logic in the verse seems to be this: the land is full of adulterers; because of this there is a curse on the land; this has resulted in a drought; the land mourns because of the drought. What becomes clear in this verse is the relationship between disobedience to Yahweh and his covenant and the disastrous consequences of this for both the land and the people (cf. Jones 1992:305). This is summarised by Fretheim (2002:33) when he says:

Moral order adversely affects cosmic order; human sin has had a deeply negative effect upon the environment (just the opposite of claims made for Baal worship on the land's fertility). ${ }^{7}$

Verse 10 concludes with a reference to the unidentified adulterers - "Their course has been evil, and their might is not right" (NRS). The key words in this sentence are the "evil (ra'ah) course" and "their might", which is inappropriate. This implies that the way they conduct their lives is evil and that they use their might wrongly. If the people mentioned here are the adulterers, then we can assume that these are the mighty, the powerful, not ordinary Judeans. The evil way in which they conduct their lives therefore includes the abuse of their power. Although the prophets are not explicitly mentioned in this verse, it is they who Jeremiah has in mind. Besides the heading, which introduces this collection of oracles (and which might be secondary), verse 9 refers to

5 Cf. Jer 4:8, 12:4, 14:2, 4.

6 Cf. Ps 65:13; Jer 9:9; Joel 1:19, 2:22.

7 Cf. Fretheim's (2002:100) discussion on moral order and cosmic order, where he discusses the interconnectedness of human behaviour and the cosmic consequences. In this regard, read also Fretheim (2002:30-33; also 34-35 - sin and judgement). 
the words of Yahweh. The prophets were the ones who conveyed Yahweh's words to the people. The speaker (presumed to be Jeremiah) is in conflict with opposition prophets who were "...the official mantic functionaries of the court and cult" (Carroll 1986:73). These opposition prophets had power because they were part of the official structures of the ruling party in Judah.

What is interesting here is the link between adultery, evil conduct, misuse of power and a curse on the land (resulting in drought). If the argument is correct (i.e. that the covenant is the backdrop against which this verse should be understood), then the evil conduct has to do with the worship of other gods besides Yahweh (cf. Honeycutt 1989:584-585). ${ }^{8}$ It seems that, throughout the land, there were people of might (power) who took the lead in displaying disloyalty to Yahweh and the violation of the covenant.

At the beginning of this paper, I argued that verses 10-12 belong together. If this is the case, then verse 11 makes it clear that verse 10 refers to the priests and the prophets. This verse contains an indictment of the priests and the prophets (Overholt 1970:51). The verb used here to describe the actions of these priests and prophets should be understood to mean "to be profane or godless". The same verb is used to mean "to be polluted". In Isaiah $24: 5$, Jeremiah $3: 1$ and 9 this verb is used to indicate that the breaking of the covenant resulted in the land being polluted.

Again, one should take note of the contrast between Yahweh's holiness referred to in 23:9 and the contrasting profanity of the priests and the prophets. These religious functionaries acted in the temple. Verse 11 says they went as far as to practise their evil ways in the temple itself, which is a holy place, the earthly abode of Yahweh himself. The same noun, which is used to qualify the nature of these religious leaders' way of conducting their lives in verse10, ra'ah, is used to describe the misconduct (wickedness) of these temple functionaries. The precise nature of this wickedness is not revealed (Lundbom 2004:183), but if there is connection with the previous verses, then it concerns the profane conduct that violates the covenant obligations. As mentioned before, this seems to refer to the worship of foreign gods, deeds that reveal disloyalty to Yahweh.

8 Yates (2007:13), in a discussion of Jeremiah 2:1-4:4, a passage related to 23:9-15, made the following statement: "Israel's sin has turned the 'fertile land' (2:7) into a barren wasteland (2:15), like the 'desert' from which Yahweh had delivered Israel (2:6). The interplay of 'land' and 'desert' most effectively demonstrates the futility of Israel's trust in fertility gods like Baal. If they had remained loyal to Yahweh, they could have enjoyed a 'fertile land' (2:7) instead they trusted in Baal and ended up with a 'desert'." 
The next verse (vs. 12) commences with laken, to indicate what the outcome will be of the evil practised by these functionaries: a proclamation of judgement.

Again, there is a reference to the way or manner these religious functionaries conduct their lives, although a different Hebrew word (the usual one is dêrêq) is used here (cf. verse 10). They are on a course that is described as slippery, dark ${ }^{9}$ and they will be driven even deeper into misery. The imagery used describes the severity of the judgement and the calamity (cf. Lundbom 2004:183). Yahweh will take action against these functionaries by bringing disaster upon them. Note the use of the noun ra'ah (evil, calamityvss 10,11$)$ to describe the nature of their punishment. Their ways of doing are described as evil (ra'ah), and at the same time Yahweh will bring evil/calamity/ disaster (ra'ah) upon them (cf. also Jer 6:19; 49:37). The "year of visitation" refers to a time of punishment.

Carroll (1986:453-454) regards verse 12 as a fitting conclusion to $23: 10$, but credits verse 11 to the redaction history of the poem under discussion. $\mathrm{He}$ is correct in saying that it is almost impossible to ascribe the poem to a specific context, but he too easily and without strong reasoning credits the redaction for both the inclusion of the reference to priests and the prophets and the oracular nature of the verse (cf. ne'um Yhwh). Here there seems to be a build up of tension and a progressive revelation of who the culprits are (i.e. the culprits addressed in this poem). Verse 9 starts off with a reference to the holiness of Yahweh, followed by a reference to the profane behaviour of the adulterers. This is followed by mourning because of the drought in the land caused by a curse - for the evil conduct by, at this stage, unknown persons. Verse 10 refers to these people as "people of might". The progression is taken a step further in verse 11 - the priests and the prophets are now named as the profane (polluted) ones, cult officials who are to be blamed for their evil (wickedness). Finally, verse 12 announces that the Holy One will, as a result, punish the "unholy" cult officials (Craigie et al 1991:337). ${ }^{10}$ If this line of argument holds true, then Carroll's view should be considered with greater circumspection.

9 Overholt (1970:51-52) views the "darkness" as a way of characterising "the life of the unrighteous (Isa. 8.22), and especially that which is sent by Yahweh against the wicked".

10 Craigie (1991:337) follows a similar line of argument by indicating how the thoughts expressed in verse 11 reach a climax when, at the end of the verse, Yahweh (in the first person) makes an accusation, followed by a messenger formula. This is followed in verse 12 by Yahweh's judgement, climaxing also in the first person singular. 


\subsection{Jeremiah 23:13-15}

These three verses consist of two oracles, one in verses 13-14 and one in verse 15 (Lundbom 2004:185). The previous verse (vs 12) ended with a concluding messenger formula, followed in verse 13 with a connecting waw. Verse 14 also has a connecting waw, followed in verse 15 with laken, which announces the resultant judgement for wrong behaviour. Jeremiah 23:13 and 14 are clearly structured to display a comparison and therefore the two verses should be read together.

Jeremiah 23:13 In the prophets of Samaria I saw a disgusting thing: they prophesied by Baal and led my people Israel astray.

Jeremiah 23:14 But in the prophets of Jerusalem I have seen a more shocking thing: they commit adultery and walk in lies; they strengthen the hands of evildoers, so that no one turns from wickedness; all of them have become like Sodom to me, and its inhabitants like Gomorrah.

Jeremiah 23:15 Therefore thus says the LORD of hosts concerning the prophets: "I am going to make them eat wormwood, and give them poisoned water to drink; for from the prophets of Jerusalem ungodliness has spread throughout the land." (NRS)

Jeremiah 23:13-15 concerns the prophets who are the objects of the collected oracles in the cycle (cf. 23:9-40). There are no longer indirect references to the prophets, as was the case in 23:10; instead, there are direct references to them and their actions. This fact is highlighted by introducing both verses 13 and 14 with reference to prophets. First the prophets of Samaria are mentioned (vs. 13) and then, in verse 14, the prophets of Jerusalem. As was the case in verse 12, where it was stated that Yahweh as first person speaker announced punishment, so it is a first person speaker who has observed how the prophets of Samaria and Jerusalem behave.

The observation in 23:13 is that, in or among the prophets of Samaria, something disgusting (NRS) or unsavoury or repulsive (NIB) or folly (KJV) is taking place ${ }^{11}$. This is qualified by an explanation: these prophets prophesy by Baal and, as a result, they lead the people to err. The covenant conditions have been violated. These actions are compared in $23: 14$ by naming something even worse (in 23:13) that has been observed among the prophets of Jerusalem

11 According to Lundbom (2004:186; 358), nebalah in the Old Testament indicates doing something scandalous, often with regards to sexual practices or something morally offensive. Holladay (1986:631) opts for the meaning "fatuous" and argues that words such as unsavoury and repulsive are too negative. By referring to Job $6: 6$, he searches for a meaning that expresses a lack of character or in terms of prophecy lacking reality (cf. Lam 2:14). 
(cf. McKane 1986:573-574; Lundbom 2004:187; Carroll 1986:255). This is described as something horrible. In Jeremiah 5:30-31, such a horrible act is also done by the prophets and they also prophesy falsely (lies- shêqêr $)^{12}$. The horrible things observed in verse 14 are again qualified by a sentence that lists all the wrongdoings of the Jerusalem prophets: they commit adultery, they live by lying, and they assist those who do evil. Holladay (1986:632) advocates for an understanding of "prophesy by lies" as implying prophesying by Baal and, because of this, understands "committing adultery" to be a metaphor for Baal worship. This implies they are unfaithful to Yahweh and proclaim false messages, which is nothing but living a lie. They pretend to be true prophets. Instead of being prophets of Yahweh who keep people from transgressing by urging them to act morally correct, the example they set to ordinary people is a bad example.

Some scholars hold the view that the reference to Sodom and Gomorrah ${ }^{13}$ serves the purpose of emphasising that the people are morally corrupt (cf. Rudolph 1968:151). ${ }^{14}$ Others claim that Sodom and Gomorrah are symbols of destruction (Overholt 1970:55; Craigie et al 1991:340; also Brueggemann 1998:210). It is true that a reference to the two cities calls to mind total destruction, but verse 14 is still part of the indictment of the prophets. It is only in verse 15 that the punishment for the wickedness is announced. Perhaps a more convincing meaning in the current context would be to understand the two cities as symbols for wickedness. Words that are similar to what we have found in 23:10-11 are repeated in this verse. These words are: "committing adultery" (na'of- same stem as in vs 10- adulterers), "walk in lies" (cf. 5:30$31)^{15}$, "doing evil" (ra'ah). Morally, these prophets do not "make the grade"; on the contrary, they act in contrast to the nature and requirements of the "Holy One" (vs 9). The emphasis here is on the condemnation of apostasy (cf. Craigie et al 1991:340).

As I said earlier on, scholars such as Rudolph, Bright, Holladay, McKane and Lundbom are of opinion that we should take the reference to adultery literally (also Jones 1992:307). A good example of this is Jeremiah 29:23, where it is stated that the prophets "have committed adultery with their

12 Cf. Jer 3:10, 5:31, 13:25, 23:14 and 29:9. Except for 3:10, all the other instances has to do with false prophecy or falsehood.

13 Cf. Gen 18:23-33.

14 Jones (1992:307) takes the reference to Sodom and Gomorrah to mean that the prophets are beyond redemption. As prophets they had to serve a particular purpose, but they have lost their way and purpose.

15 In Jeremiah 5:30-31 both the words "horrible thing" and "lies" appear as in 23:14. Jeremiah 5:30 An appalling and horrible thing has happened in the land. 5:31 the prophets prophesy falsely, and the priests rule as the prophets direct; my people love to have it so, but what will you do when the end comes? 
neighbours' wives and have spoken in my name lying words" (NRS). The argument would then be that the mention of Sodom and Gomorrah seems to support this view, for these two cities were famous for their sexually immorality (Loader 1990:61; 1991:13). This may be true in most instances where the two cities are mentioned, but in the current context - where apostasy seems to be the real concern, particularly the comparison with Baal worship - it is more likely that the reference to adultery should not be taken literally to mean sexual misbehaviour (cf. Jer 9:2 "...for they are all adulterers, a crowd of unfaithful people"). As Sodom and Gomorrah did not escape the judgement of Yahweh, neither would the prophets of Judah (cf. Schreiner 1981:138; Fretheim 2002:334). Brueggemann aptly summarises verse 14 (1998:210) when he says "...in all likelihood what is under indictment is a destructive, disobedient, noncovenantal way of ordering every aspect of community life".

The final verse of this section, verse 15 , brings the indictment to the point of judgement. Introduced by the particle laken, it is pronounced that Yahweh will poison the prophets. This judgement is motivated by a sentence introduced with $k i$, blaming these prophets of Jerusalem for causing ungodliness (profaneness) to spread throughout the land. Again the reference is to profaneness or pollution, which again stands in contrast to the holiness of Yahweh (cf 23:9).

It should be noticed that, in Jeremiah 9:15, a judgement similar to 23:14 is pronounced.

Jeremiah 9:14 ...but have stubbornly followed their own hearts and have gone after the Baals, as their ancestors taught them. 15 Therefore thus says the LORD of hosts, the God of Israel: "I am feeding this people with wormwood, and giving them poisonous water to drink" (NRS).

There is, however, an exception that "this people" (the people of Judah) are the receivers of the judgement in 9:15, whereas the prophets are addressed in 23:15. The context of 9:15 is that the people have not obeyed Yahweh's laws and have instead worshipped the Baals. In 23:15 the prophets are blamed for spreading profaneness (ungodliness) throughout the land and, in so doing, polluting the land. The transgression here is not explicitly spelled out, but we can assume that the prophets have done things that violated the stipulations of the covenant. In all probability, the worship of foreign gods is meant here.

\section{JEREMIAH 23:9-12 AND 23:13-15: DO THEY BELONG TOGETHER?}

Do 23:9-12 and 23:13-15 belong together? Should they, therefore, be interpreted together? In the discussion of these two sections, it became clear 
that they are closely linked together and interconnected. Many of the concepts between the two sections are common and the ideas in the one section support those in the other section (Holladay 1986:630). In fact, 23:13-15 drives the point of the transgressions of the prophets even stronger than 23:9-12, and puts the prophets clearly in the centre of the controversies addressed in the cycle on the prophets (cf. Overholt 1970:52). Whether these two sections were originally one oracle cannot be established beyond all doubt. The same is true for regarding them as two separate oracles, since they are intricately interrelated in the current context.

\section{GENERAL OBSERVATIONS AND CONCLUSIONS}

It seems from the discussion above and from engaging the book of Jeremiah in general that social and moral conditions in Judah were, indeed, dire. With the discovery of the law code and the ensuing reformation efforts by King Josiah, Judah's depraved state was clearly acknowledged (cf. Oosterhoff 1990:39; Holladay 1986:1). Kings and leaders themselves were to be blamed for their failure to establish social justice and exercise good governance. This resulted in a society in which the leadership became self-consumed and failed to take responsibility for keeping the covenant and the stipulations that accompanied it. Jeremiah was extremely troubled by the moral decay and the lack of leadership he witnessed. The ongoing threat of other religious practices such as Baal worship encouraged people to indulge in syncretistic worship practices (cf. Albertz 1994:170-176; Gerstenberger 2002:201-203). While Jeremiah promoted the worship of Yahweh alone (cf. Lang 1983:40; Domeris 1999:256-257), many others engaged in a syncretistic worship of Yahweh. To describe these practices, which Jeremiah regarded as a violation of the covenant with Yahweh, he used terminology such as adultery or marital unfaithfulness (cf. Jer 3). ${ }^{16}$

The unfaithfulness of Israel and Judah is often described using terminology that alludes to sexual transgressions. It is sometimes difficult to distinguish

16 In a lengthy article, Domeris (1999: 244-271) discusses the concept of antilanguage which was applied in the book of Jeremiah to express the views of an opposition position to that of the official and dominating position in Judean society. Gottwald (1985:403) calls the first group the "autonomists" and the group Jeremiah would sympathise with the "coexisters" (also Long 1981:48-49). Domeris has illustrated that the use of metaphors in Jeremiah was, in particular, applied for the purpose of "antilanguage". The application of metaphors in Jeremiah 23:9-15 illustrates this point quite clearly. Domeris regards this language as exaggerated use of language, probably from a group who promoted the Yahweh-alone position of worship to which Jeremiah probably belonged to (cf. also Carroll 1986:126-127 and Diamond 2003:575). 
between adulterous practices that refer to Baal worship or idolatry and immoral practices such as infidelity in marriage. The imagery used might imply all of these indiscretions. Disloyalty to Yahweh and the covenant is often described by terminology that has sexual overtones (cf. Oosterhoff 1990:118).

It also seems from the argument presented in this paper that there is a strand in the book of Jeremiah that works with the notion of a causal relationship between evil (wicked, profane) ways of living and the pollution of the land. In this regard Schreiber (2010:161-162) says: "In Jeremiah's time, his people and other people were destroying nature by their immoral pagan practices." This resulted in the land being cursed because the covenant relationship with Yahweh had been violated.

In Jeremiah 3:2, the people of Israel are blamed for having affairs with lovers on the hilltops. By doing so, they have polluted the land (cf. vss 1 and 2). As a result, Yahweh will keep back the rains. In this instance there is a direct link between unbecoming moral behaviour and the effect on the land. This poetic section goes over to a prose section in 3:6 that refers to the time of King Josiah (cf. Schmidt 2008:105). Again it is stated that Israel committed adultery on every mountain and under every tree (cf. 2:20, 3:6, 13, 17:2). Judah was in a position to observe all of these evil practices in his own day. Verse 9 makes it clear that Israel committed adultery by worshiping idols of stone and wood. Judah, who also witnessed this, returned to Yahweh, but half-heartedly, with pretence, and therefore falsely (shêqêr).

From 3:11 onwards a comparison between Israel and Judah is drawn, judging Judah to be worse than Israel. What is important to note is what is said in 3:13: Judah should confess that she has been rebellious against Yahweh by her worship of foreign gods "under every green tree". Her actions are regarded as disobedience against Yahweh. What is important for the argument put forward in this paper is the matter of Judah worshipping foreign gods, and therefore polluting the land. And because of the pollution of the land, no rain will fall, which means that there will be drought.

From the discussion above, there seems to be strong indications of a strand of thought in the book of Jeremiah which establishes a link between wrongful behaviour by people and droughts in the land. This leads to the question whether there is actually an encounter between Yahweh and the gods. Baal is a storm and rain god and consequently a vegetation god. He is worshipped because he brings rain and good harvests (cf. Phelps 2000:134-135). Baal is often associated with the fertility of the earth (cf. Brueggemann 2002:1516). Mention is often made of the worship of gods under every green tree (cf. $3: 13)$. Yahweh's response to this is by countering the benefits expected by the people by withholding the rains (3:3) and placing a curse on the land (23:10). 
This idea is further supported by Jeremiah 14 where, again, lack of rain, drought and famine are the result of "turning away from Yahweh", disloyalty to the covenant God. What is interesting in chapter 14 is the fact that the prophets are opposed and regarded as false, because they are not commissioned by Yahweh. They deliver false (shêqêr) messages; they are nothing less than liars. This corresponds to what we find in Jeremiah 23:9-40.

If the arguments put forward hold true, then it does not seem farfetched to conclude that Jeremiah 23:9-15 promotes the idea that adultery is one of the criteria why some prophets should be regarded as false prophets. If 23:13-15 is regarded as part of the sections 23:9-15, then the reference to Baal should be seen as part of a polemic against the rain and vegetation god. Yahweh as covenant God is also the God of creation, which is why he will punish the land by drought - because it is polluted. ${ }^{17}$

To conclude: The passage 23:9-15, as part of the oracles against the "false" prophets, contributes to "the bitter disillusionment with prophecy" experienced by people who suffered the events of 586 BCE (Nicholson 1970:103). The false prophets, with their adulterous way of living, are part of a leadership that failed the people of Judah and Yahweh.

\section{BIBLIOGRAPHY}

Albertz, R.

1994. A history of Israelite religion in the Old Testament period. From the beginnings to the end of the Exile, vol 1, trl by Bowden, J. London: SCM.

Brueggemann, W.

1997. Theology of the Old Testament. Testimony, Dispute, Advocacy. Minneapolis: Fortress Press.

1998. A Commentary on Jeremiah. Exile \& Homecoming. Grand Rapids, Michigan: Eerdmans Publishing Company.

2002. Reverberations of Faith. A Theological Handbook of Old Testament Themes. Louisville: Westminster John Knox.

CARroll, R.P.

1986. Jeremiah. A commentary. London: SCM (OTL).

17 Brueggemann (1997:528-551) offers an insightful discussion of Creation as Yahweh's partner. He refers to the freedom of Yahweh as Creator, but also points out that, in Israel's rhetoric, Yahweh's freedom is never free from moral condition. The moral conditions are mandated by the covenant stipulations (1997:543). In Jeremiah 23:10, Yahweh's curse on the land results in drought and mourning. This all happens because of the disregard of the moral stipulations of the covenant law. 
Craigie, P.C., Kelly, P.H. \& Drinkard Jr, J.F. 1991. Jeremiah 1-25. Dallas, Texas: Word Books, Publisher (Word Biblical Commentary).

DE WAARD, J. 2003. A Handbook on Jeremiah. Winona Lake, Indiana: Eisenbrauns.

DIAMOND, A.R.P. 2003. Jeremiah. In: J.D.G. Dunn \& J.W. Rogerson, (eds.). Eerdmans Commentary on the Bible. (Grand Rapids, Michigan: Eerdmans), pp. 543-559.

DOMERIS, W.R. 1999. When metaphor becomes myth: A socio-linguistic reading of Jeremiah. In: A.R.P. Diamond, K.M. O'Connor \& L. Stulman (eds.). Troubling Jeremiah. (Sheffield: Sheffield Academic Press), pp. 244-262.

Duнm, B. 1901. Das Buch Jeremia. Tübingen: JCB Mohr.

FRETHEIM, T.E. 2002. Jeremiah. Macon, GA: Smyth \& Helwys Publishing.

Gerstenberger, E. S. 2002. Theologies of the Old Testament. London: T\&T Clark.

GotTWALD, N.K. 1985. The Hebrew Bible- a socio-literary introduction. Philadelphia: Fortress Press.

HOLLADAY, W.L. 1986. Jeremiah 1. A Commentary on the Book of the Prophet Jeremiah Chapters 1-25. Philadelphia: Fortress Press.

HONEYCUTT, R.L.

1989. Jeremiah 23:9-40. Review and Expositor 86:583-594.

HUEY, F.B. JR 1993. Jeremiah, Lamentations. Nashville, Tennessee: Broadman Press (The New American Commentary).

JONES, D.R. 1992. Jeremiah. Grand Rapids, Michigan: Eerdmans (New Century Bible Commentary).

LANG, B.

1983. Monotheism and the prophetic minority. Sheffield: The Almond Press.

LOADER, J.A.

1990. A tale of two cities: Sodom and Gomorrah in the Old Testament, early Jewish and early Christian tradition. Kampen: Kok.

1991. The prophets and Sodom: The prophetic use of the Sodom and Gomorrah theme. HTS 47(1):5-25. 
LONG, B.O.

1981. Social dimensions of prophetic conflict. Semeia 21:31-53.

LUNDBOM, J.R.

2004. Jeremiah 21-36. A new translation with introduction and commentary. New York: Doubleday (The Anchor Bible).

McKane, W.

1986. A critical and exegetical commentary on Jeremiah. Edinburgh: T \& T Clark (ICC).

Nicholson, E.W.

1970. Preaching to the exiles. A study of the prose tradition in the book of Jeremiah. Oxford: Basil Blackwell.

OOSTERHOFF, B.J.

1990. Jeremia. Kampen: Uitgeversmaatchappij J H Kok (COT).

OVERHOLT, T.W.

1970. The Treat of Falsehood. A Study in the Theology of the Book of Jeremiah. London: SCM.

Phelps, M.A.

2000. Baal. In: D.N. Freedman (ed.). Eerdmans Dictionary of the Bible. (Grand Rapids, Michigan: Eerdmans Publishing Company), pp. 134-135.

RudOLPH, W.

1968. Jeremia. 3. verbesserde Aufl. Tübingen: J C B Mohr.

SCHMIDT, W.H.

2008. Das Buch Jeremia. Kapitel 1-20. Götingen: Vandenhoeck \& Ruprecht (ATD 20).

SCHREIBER, M.

2010. The man who knew God. Decoding Jeremiah. Lanham, Maryland: Lexington books.

SCHREINER, J.

1981. Jeremia 1-25,14. Würzburg: Echter Verlag (Die Neue Echter Bibel).

SHARP, C.J.

2003. Prophecy and Ideology in Jeremiah. Struggles for authority in the DeuteroJeremianic Prose. London: T\&T Clark.

STULMAN, L.

2005. Jeremiah. Nashville: Abingdon Press (Abingdon Old Testament Commentaries).

THOMPSON, J.A.

1980. The book of Jeremiah. Grand Rapids: Eerdmans. 
WEISER, A.

1969. Das Buch Jeremia. Göttingen: Vanderhoeck \& Ruprecht (ATD).

WERNER, W.

1997. Das Buch Jeremia. Kapitel 1-25. Stuttgart: Verlag Katholisches Bibelwerk (Neuer Stuttgarter Kommentar).

YATES, G.E.

2007. The call for the unfaithful wife to return: The rhetoric of prophetic appeal in Jeremiah 2:1-4:4. [Online.] Retrieved from: http://digitalcommons.liberty.edu/ Its_fac_pubs/11, 1-31.

Keywords

Jeremiah

False prophets

Adultery

Baal
Trefwoorde

Jeremia

Valse profete

Ontug

Baal 